\title{
Recent advances in the molecular epidemiology of leprosy
}

\author{
Masanori MATSUOKA* \\ Department of Bioregulation, Leprosy Research Center, National Institute of Infectious Diseases, Tokyo, Japan
}

[Received / Accepted: 24 Sept. 2008]

Key words : leprosy, molecular epidemiology, Mycobacterium leprae, SNPs, VNTRs

Recent advances in the molecular epidemiology of leprosy through genotyping of variable number tandem repeats (VNTRs) and single nucleotide polymorphisms (SNPs) are described. VNTRs with a broad range of diversity are useful genotyping tools for analyzing transmission in community areas, and SNPs and VNTRs with a small degree of variation are favorable for investigating the global transmission of leprosy. We expect that the transmission of leprosy can be fully analyzed by the application of these new methodologies.

\section{Introduction}

The number of newly detected cases of leprosy has been gradually decreasing around the world in recent years ${ }^{1)}$. Even so, some details of disease transmission remain to be elucidated. One of the important subjects still under dispute, and essential for establishing a better strategy for preventing new cases, is the transmission mode of leprosy including the infectious source. Phenotype, serotype, phage type and genotype are robust metrics for analyzing and tracing transmission in many infectious diseases ${ }^{2,3)}$. These useful tools were not available

*Corresponding author :

Department of Bioregulation, Leprosy Research Center, National Institute of Infectious Diseases

4-2-1, Aobacho, Higashimurayama-Shi, Tokyo 189-0002, Japan.

TEL : +81-42-391-8211 FAX : +81-42-394-9092

E-mail :matsuoka@nih.go.jp for understanding the transmission of leprosy until two kinds of variable number tandem repeat (VNTR) were identified ${ }^{4,5}$, followed by the discovery of single nucleotide polymorphisms (SNPs) in the Mycobacterium leprae genome ${ }^{6}$. Epidemiological studies of leprosy using these two assays have been gradually accumulating since 2004, and findings generated by these breakthroughs in molecular epidemiology are now taking the place of classical epidemiological methods. An international study group for investigating the transmission of leprosy through the application of advances in molecular biology, including genotyping, has been organized and collaborative studies have begun ${ }^{7)}$. VNTRs with broad allelic diversity are useful for analyzing transmission patterns in the community ${ }^{8-11)}$. SNPs and VNTRs with a narrow range of diversity are practical for characterizing the global geographical distribution of different genotypes of $M$. leprae, 
and are beneficial in tracing the dissemination of leprosy in prehistoric times and following current global leprosy migration patterns ${ }^{12-16)}$. This article describes recent advances in the molecular epidemiology of leprosy.

\section{Application of VNTRs to Analyze the Transmission of Leprosy}

It has long been believed that leprosy is transmitted by heavy contact with leprosy patients; however, there are some findings which contradict this premise. For instance, a study on the geographical distribution of responders to $M$. leprae antibodies showed a distribution of positive responders in houses remote from those with known patients ${ }^{17}$. The limited effect of chemoprophylaxis ${ }^{18)}$ means that drugs prevent the progression of an active infection to overt disease ${ }^{19)}$ but do not interrupt transmission. Attempts to curtail transmission and reduce new infections by chemoprophylaxis in the Federated States of Micronesia (FMS) failed. The number of new cases detected in FMS has increased again after 1999 and over the last several years has risen to nearly the same level as before execution of the chemoprophylaxis program ${ }^{1}$. Many new cases without known contact with leprosy patients ${ }^{20,21)}$ have also been reported. These findings suggest gaps in the traditional concept of leprosy transmission and imply the existence of an infectious source of M. leprae other than leprosy patients.

PCR studies have shown that in areas with a high prevalence of leprosy, many individuals harbor $M$. leprae in their nasal mucus ${ }^{22,23)}$. These findings indicate that people in such areas are frequently exposed to $M$. leprae infection. The hypothesis that the bacterial genotypes from household members or other contacts of patients should be identical if the bacilli are transmitted by contact with the patient, was tested by a comparison of genotypes from the nasal mucus of patients and family members, and also from new patients and the supposed index case of a multifamily case ${ }^{8}$. Genotyping based on the copy number of a TTC repeat ${ }^{5,8)}$ and another genotyping method with higher discriminatory power were applied ${ }^{10)}$. Results revealed that the genotype of $M$. leprae in the nasal mucus differed between the patient and contacts in a given household. The existence of $M$. leprae strains with allelic diversity in a multifamily case in China was also shown ${ }^{11)}$. On the other hand, a study conducted in India revealed no divergence among the three VNTRs from two patients in a multifamily case ${ }^{9)}$. The lack of divergence among the patients of this case could be explained by the low discriminatory power of genotyping using only three polymorphic VNTRs. In another study, isolates determined as having identical genotypes using a few VNTRs were separated into different genotypes by a method with high resolution power using a combination of other appropriate VNTRs ${ }^{10}$. Thus, we theorize that the Indian clinical isolates with identical genotypes might be classified into different genotypes with the improved methodology. Although VNTRs seem to fluctuate in biopsy samples from the same patient ${ }^{24,25)}$, co-infection of $M$. leprae strains with different VNTRs may occur. While the variation of VNTRs in a given patient is often by only one or two copies, the TTC copy number of the isolate from a supposed index case was 18 and the TTC copy number of the bacilli from his son was 10 in one multifamily case report ${ }^{8)}$. It is clear that the genotypes of the bacilli from father and son were distinct and hence did not come from the same infectious source ${ }^{8)}$. This suggests the presence of an alternate source of infection.

Water sources used daily by people in an endemic area are thought to be a potential source 
of $M$. leprae infection, since many water-borne mycobacterial infectious diseases exist ${ }^{26,27,28)}$. Water samples collected at 6 villages with a high prevalence of leprosy in Indonesia were assayed by PCR. Of 44 water samples, 21 were positive by PCR assay for a $65 \mathrm{kDa}$ protein coding sequence ${ }^{29)}$. The relative risk of leprosy infection was 3.24 for those using the PCR-positive water source for washing and bathing, but no difference was shown in risk for water used for drinking and cooking. Water is heated for drinking and cooking, and consequently bacilli in the water are inactivated ${ }^{29}$. PCR positivity does not prove the existence of live $M$. leprae in the water. However, reverse transcriptionPCR (RT-PCR) targeting 16s rRNA did detect the presence of $M$. leprae organisms ${ }^{30}$. This method was used to analyze the water from wells in a village on the Indonesian island of North Sulawesi that has many newly detected patients every year. Of 51 well water samples, 17 were positive by RTPCR ${ }^{31)}$. These results strongly suggest that water is an environmental reservoir of $M$. leprae and an infectious source of leprosy. Possible infection from the soil has also not been ruled out ${ }^{32)}$.

\section{Application of SNPs and VNTRs with a Small Range of Diversity to Analyze the Global Dissemination of Leprosy}

Using a VNTR with either 3 or 4 copies of a 6-bp sequence, a pattern in the global geographical distribution of $M$. leprae has been found ${ }^{4,12,13,15,16)}$. The 3-copy strain is overwhelmingly predominant in most countries around the world, while the 4-copy strain is predominantly found in East Asia, including the mainland of Japan, Korea and eastern parts of China, as well as western parts of Mexico ${ }^{4,12-14)}$. No 4-copy isolates have been obtained from the Okinawa and Amami Islands of Japan. These islands are located at the southern end of Japan and have their own unique culture. The presence of different genotypes between these two regions of Japan is also found in other species of microorganisms ${ }^{33,34)}$. It is thought that the predominance of the 4-copy strain in East Asian countries was established in prehistoric times by the movement of Mongoloid people in the region. In Japan, it is likely that the characteristic distribution of each genotype was established by the movement of two ethnic groups which migrated to Japan about 30,000 years ago through the Okinawa Islands, and 2,800 to 1,700 years ago through the Korean peninsula ${ }^{35)}$. Specifically, $M$. leprae of the 4-copy strain might have been carried by the people who migrated to Japan through the Korean Peninsula, while the 3-copy strain was spread to the Okinawa Islands by the people who migrated to Japan from Southeast Asia 30,000 years ago. This example demonstrates how VNTRs with small range of polymorphic variation, such as that of the rpoT gene, are useful in tracing the global transmission of leprosy.

The geographical distribution of $M$. leprae SNP alleles 1-4 is also suitable for analyzing the global spread of leprosy ${ }^{6}$. An assay using a combination of SNPs and the rpoT gene VNTR was applied to determine whether Japanese Brazilian patients newly diagnosed in the mainland of Japan had been infected in Japan or Brazil ${ }^{14)}$. SNP type 4, detected in two Japanese Brazilian patients, was not found among 46 Japanese patients from the mainland. The isolate with SNP type 3 and the 3 -copy polymorphism of the rpoT gene, found in 7 isolates from Japanese Brazilian cases, is also uncommon in mainland Japan. Thus it is most likely that the patients were infected in Brazil and developed symptoms of leprosy after they came to Japan. It had been generally assumed that this was the case since the prevalence of leprosy is high in 
Brazil, but there was no substantial microbiological evidence to support the idea. The assay combining SNPs and the rpoT gene VNTR clearly contributed to the analysis of the global transfer of leprosy incident to the current movement of people.

The distribution of each SNP genotype in Asian countries was also examined in another study ${ }^{14}$. Most of the isolates (26 of 29) from Myanmar had SNP type 1. The frequency of this SNP declines in proportion to the distance of the countries from India, as is seen by low proportions in Indonesia, Korea and Japan. Logically, the SNP type 2 isolate could be derived from a type 1 progenitor, followed by evolution to type 3 and type 4 derivatives. All isolates from the southern part of India had SNP type $1^{6}$. Taken together with data from other studies, it seems likely that leprosy originated in the Indian subcontinent and spread outward to other areas of the world. This idea is compatible with the argument that leprosy originated in the Indian subcontinent and was introduced to Egypt as a result of Persian invasion during the sixth century $\mathrm{BC}$ or by the troops of Alexander the Great in the fourth century $\mathrm{BC}^{36)}$.

The use of molecular epidemiology through the application of genotyping as a means of tracking the transmission of leprosy began just 4 years ago in 2004, on the basis of a milestone discovery of two VNTRs in the genomic DNA of $M$. leprae. This new field of leprosy research is expected to illuminate obscure mechanisms of leprosy transmission with respect to sources, reservoirs, modes of transmission and the history of leprosy.

\section{References}

1) WHO: Global leprosy situation, beginning 2008. Weekly epidemiological record. 83: 293300, 2008 (http://www.who.int/wer/en/).

2) Van Duijkeren E, Wannet WJ, Housewers DJ, van Pelt W: Serotype and phage type distribution of salmonella strains isolated from humans, cattle, pigs, and chicken in Netherland from 1984 to 2001. J Clin Micrbiol 40: 39803985, 2002.

3) Van Soolingen D: Molecular epidemiology of tuberculosis and other mycobacterial infections: main methodologies and achievements. J Int Med 249: 1-26, 2001.

4) Matsuoka M, Maeda S, Kai M, Nakata N, Chae GT, Gillis TP, Kobayashi K, Izumi S, Kashiwabara Y: Mycobacterium leprae typing by genomic diversity and global distribution of genotypes. Int J Lepr 68: 121-128, 2000.

5) ShinYC, Lee H, Lee H, Walsh GP, Kim JD, Cho SN: Variable numbers of TTC repeats in Mycobacterium leprae DNA from leprosy patients and use in strain differentiation. J Clin Microbiol 38: 4535-4538, 2000.

6) Monat M, Honore N, Garmier T, Araoz R, Copee JY, Lacroiz C, Sow S, Spencer JS, Truman RW, Williams DL, Gelber R, Virmond M, Flageul B, Cho SN, Ji B, Paniz-Mondolf A, Convit J, Young S, Fine PE, Rasolofo V, Brennan PJ, Cole ST: On the origin of leprosy. Science 308: 1040-1042, 2005.

7) Aseffa A, Brennan P, Dockrell H, Gills T, Hussain R, Oskam L, Richardson JH: Report on the first meeting of the IDEAL (Initiative for Diagnostic and Epidemiological assays for Leprosy) Consortium held at Armauer Hansen Research Institute, ALERT, Addis Ababa, Ethiopia on 24-27 October 2004. Lepr Rev 76: 147-159, 2005.

8) Matsuoka M, Zhang L, Budiawan T, Saeki K, Izumi S: Genotyping of Mycobacterium leprae on the basis of polymorphism of TTC repeats for analysis of leprosy transmission. J Clin Microbiol 42: 741-745, 2004.

9) Young SK, Taylor GM, Jain S, Suneetha 
LM, Suneetha S, Lockwood DN, Young DB: Microsatellite mapping of Mycobacterium leprae populations in infected humans. $\mathrm{J}$ Clin Microbiol 42: 4931-4936, 2004

10) Zhang L, Budiawan T, Matsuoka M: Diversity of potential short tandem repeats in Mycobacterium leprae and application for Molecular typing. J Clin Microbio 43: 5221-5229, 2005.

11) Weng $X$ Wang $Z$, Liu J, kimura M, Black IV WC, Brennan PJ, Li H, Vissa VD: Identification and distribution of Mycobacterium leprae genotypes in a region of high leprosy prevalence in China: a 3-year molecular epidemiological study. J Clin Microbio 45: 1728-1734, 2007.

12) Chae GT. Lee SB, Kang TJ, Shin HK, Kim JP, Ko YH, Kim SH, Kim NH: Typing of clinical isolates of Mycobacterium leprae and their distribution in Korea. Lep Rev 73: 41-46, 2002.

13) Matsuoka M, Zhang L, Fafutis M, Legua P, Wiens C: Polymorphism in the rpoT gene in Mycobacterium leprae isolates obtained from Latin American countries and its possible correlation with the spread of leprosy. FEMS Microbiol Lett 243: 311-315, 2005.

14) Matsuoka M, Lopez Roa RI, Budiawan T, Kyaw K, Chae GT: Genotyping analysis of Mycobacterium leprae isolates from Japan and other Asian countries reveals a global transmission pattern of leprosy. FEMS Microbiol lett 261: 150-154, 2006.

15) Lavania M, Katoch K, Sigh H, Das R, Gupta AK, Sharma R, Chauhan DS, Sharma VD, Sachan P, Sachan S, Katoch VM: Predominance of three copies of tandem repeats in proT gene of Mycobacterium leprae from Northern India. Infect Genet Evol 7: 627-631, 2007.

16) Srisungam S, Rudeeaneksin J, Wattanpokayakit S, Pasadorn S, Tragoolpua R, Suwanrit S, Sawanpanyalert P, Phetsuksiri B: Typing of
Thai clinical isolates of and analysis of leprosy transmission by polymorphism of tandem repeat. Southeast Asian J Trop Med Public Health 38: 714-720, 2007.

17) Abe M, Ozawa T, Minagawa F, YoshinoY: Immunoepidemiological studies on studies on substantial infection in leprosy II. Geographical distribution of seropositive responders with special reference to their possible source of infection. Int J Lepr 59:162-168, 1990.

18) Moet FJ, Pahan D, Oskam L, Richardus JH: Effectiveness of single dose rifampicin in preventing leprosy in close contacts of patients with newly diagnosed leprosy: cluster randomised controlled trial. BMJ doi:10.1136/ bmj. 395000.885752. BE, 2008.

19) Smith CM, and Smith WCS: Chemoprophylaxis is effective in the prevention of leprosy in endemic countries: a systematic review and meta-analysis. J Infect 41:137-142, 2000.

20) Fine PE, Sterne JM, Ponnighaus JM, Bliss L, Saui J, Chihana A, Munthali M, Warandorff DK: Household and Dwelling contacts as risk factors for leprosy in northern Malawi. Am J Epidemiol 146:91-102, 1997.

21) Nordeen SK The epidemiology of leprosy. In: Hastings RC (eds) Leprosy, $2^{\text {nd }}$ edn. Churchill Livingstone, cp 3, pp 29-45

22) Saeki K, Budiawan T, Matsuoka M, Izumi S: Epidemiological significance of Mycobacterium leprae in the residential environment: Detection of $M$. leprae on the surface of nasal cavity of inhabitants in a leprosy endemic area using the polymerase chain reaction (in Japanese). Jap J Dermatol 110:153-160, 2000.

23) van Beers SM, Izumi S, Madjid B, Maeda Y, Day R, Klatser PR: An epidemiological study of leprosy infection by serology and polymerase chain reaction. Int J Lepr 62:1-91, 1994. 
24) Monot M, Honore N, Baliere, Ji B, Sow S, Brennan, PJ, Cole ST: Are variable-number tandem repeats appropriate for genotyping Mycobacterium leprae. J Clin Microbiol 46: 2291-2297, 2008.

25) Young SK, Ponnighaus LM, Jain S, Lucas S, Suneetha S, Lockwood DNJ, Young DB, Fine PEM: Use of short tandem repeat sequences to study Mycobacterium leprae in leprosy patients in Malawi and India. PLoS Ngl Trop Dis 2:e214, 2008.

26) Goslee S, Wolinsky E: Water as a source of potentially pathogenic mycobacteria. Am rev Resp Dis 113:287-292, 1976.

27) Gruft H, Loder A, Osterhout M, Parker B, Falkinham III JO: Postulated source of Mycobacterium intracellulare and Mycobacterium scrofulaceum infection: Isolation of Mycobacteria from estuaries and ocean waters. Am Rev Resp Dis 120:1385-1388, 1979.

28) Stinear T, Johson PDR: First isolation of $M y$ cobacterium ulcerans from an aquatic environment: The end of a 60-years search. PLoS Ngl Trop Dis 2:e216, 2008.

29) Matsuoka M, Izumi S, Budiawan T, Nakata $N$, Saeki K: Mycobacterium leprae DNA in daily using water as a possible source of leprosy infection. Ind J Lepr 71:61-67, 1999.

30) Kurabachew M, Wondimu A, Ryon JJ: Reverse transcription-PCR detection of Mycobacterium leprae in clinical specimens. J Clin Micobiol 36: 1352-1356, 1998.

31) Matsuoka M, Budiawan T, Mukai T, Gidoh M, Izumi S: Quantification and evaluation of
Mycobacterium leprae viability found in water in a leprosy endemic area. Abstract of U.S.Japan cooperative medical sciences program, Forty-third Tuberculosis and leprosy research conference. 2008.

32) Lavania M, Katoch K, Sachan P, Dubey A, Kapoor S, Kashyap M, Chauhan DS, Sigh HB, Sharma VD, Jadhav RS, Katoch VM: Detection of DNA from soil samples by PCR targeting RLEP sequences. J Comm Dis 38: 269373, 2006.

33) Falush D, Wirth T, Linz B, Pritchard JK, Stephens M, Kidd M, Blaser MJ, Graham DY, Vacher S, Perez-Perez GI, Yamaoka Y, Megraud F, Otto K, Reichard U, Katzowitsch E, Wang X, Achtman M, Suerbaum S: Traces of human migrations in Helicobacter pylori populations. Science 299: 1582-1585, 2003

34) Sugimoto C, Kitamura T, Guo J, Al-Ahdal MN, Shchelkunov SN, Otova B, Ondrejka P, Chollet J-Y, El-Safi S, Ettayebi M, Grésenguet G, Kocagöz T, Chaiyarasamee S, Thant KZ, Thein S, Moe K, Kobayashi N, Taguchi F, Yogo Y: Typing of urinary JC virus DNA offers a novel means of tracing human migrations. Proc Nat Aca Sci USA 94: 9191-9196, 1997

35) Hanihara K: Dual structure model for the population history of the Japanese. Japan Review 2: 1-33, 1991.

36) Trautman JR: The history of leprosy. In: Hastings RC (eds) Leprosy, $2^{\text {nd }}$ edn. Churchill Livingstone, cp 2, pp 11-25 


\section{ハンセン病の分子疫学解析における最近の知見}

\section{松岡 正典*}

国立感染症研究所ハンセン病研究センター生体防御部

〔受付・掲載決定：2008 年 9 月 24 日]

キーワード : ハンセン病、分子疫学、らい菌、SNPs、VNTRs

らい菌遺伝子の直列繰返配列多型（variable number tandem repeat：VNTRs）及び 1 塩基多型（single nucleotide polymorphism: SNPs）を用いたハンセン病の分子疫学の最近の知見が述べられた。VNTRs は地 域社会を対象としたハンセン病の伝搬の解析にまた、SNPs 並びに多様性の小さな VNTRs はハンセン病の 地球規模での伝搬の解析に有用であることが述べられた。これらの手技をもちいることにより、ハンセン 病の感染様式がより明確にされることが期待される。

* Corresponding author: 国立感染症研究所ハンセン病研究センター生体防御部

干 189-0002 東京都東村山市青葉町 4-2-1

TEL : 042-391-8211 FAX : 042-394-9092

E-mail :matsuoka@nih.go.jp 